\title{
Alienation in Neoliberal India and Bangladesh: Diversity of Mechanisms and Theoretical Implications
}

Shapan Adnan

\section{OpenEdition}

\section{Journals}

Electronic version

URL: http://journals.openedition.org/samaj/4130

DOI: $10.4000 /$ samaj.4130

ISSN: 1960-6060

Publisher

Association pour la recherche sur l'Asie du Sud (ARAS)

\section{Electronic reference}

Shapan Adnan, «Alienation in Neoliberal India and Bangladesh: Diversity of Mechanisms and Theoretical Implications », South Asia Multidisciplinary Academic Journal [Online], 13 | 2016, Online since 06 April 2016, connection on 02 May 2019. URL : http://journals.openedition.org/samaj/4130 ; DOI : 10.4000/samaj. 4130

This text was automatically generated on 2 May 2019.

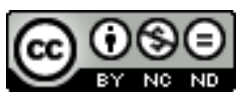

This work is licensed under a Creative Commons Attribution-NonCommercial-NoDerivatives 4.0 International License. 


\title{
Alienation in Neoliberal India and Bangladesh: Diversity of Mechanisms and Theoretical Implications
}

\author{
Shapan Adnan
}

\section{Introduction}

1 Alienation of land is hardly new to South Asia and has been a historically ongoing process. ${ }^{1}$ Also termed 'land appropriation' or 'land grab', the process involves the transfer of rights over land of one party to another. Since property rights or titles to land may not always be clear, it is convenient to define 'land alienation' as the transfer of effective or de facto control over land, rather than formal or de jure rights of ownership and operation (Hall 2013: 1585).

2 The colonial state undertook large-scale acquisition of land in British India for building major infrastructure such as railways and setting up state forests and plantations (Mohsin 1997). During the decades following independence in 1947, the post-colonial South Asian states acquired private and common lands for 'public purpose', typically for large-scale infrastructure constructions and development projects (Walker 2008: 580). Such state acquisition of land resulted in massive development-induced dispossession. It is estimated that ' 60 million people were displaced by development projects in India between 1947 and 2004' (Hall 2013: 1588).

3 With the onset of neoliberal globalization from the 1970s, there has been a qualitative shift in the nature and purpose of land acquisition in India and Bangladesh. ${ }^{2}$ In contrast to its traditional use as the means of production in agriculture and forestry, land has increasingly become a commodity with high value that can be transacted profitably in real estate and financial speculation. The features of land appropriation in the era of 
neoliberal globalization display both continuity and change in relation to corresponding processes in earlier periods. While state acquisition of land has continued, the purpose has shifted increasingly towards supplying private corporations and elite groups controlling finance capital for investment. Moreover, a range of non-state actors, including multinational corporations, have become directly involved in appropriating land on an increasing scale. In addition to large-scale acquisitions, 'everyday forms of land grabbing' targeting weaker social groups have become significant (see Feldman in this volume). The combination of these trends has given rise to the contemporary phenomena of land grabs in India and Bangladesh, as in many other parts of the world.

4 Given the wide range of processes, mechanisms and agencies characterizing contemporary land alienation, an appropriate theoretical framework is necessary for comparative analysis. The major existing theoretical approaches to land alienation are based on (i) Marx's (1976, 2010: 500-02) concept of primitive accumulation in the process of capitalist development and (ii) the derivative notion of accumulation by dispossession (ABD) formulated by Harvey (2005) in the context of neoliberal globalization (Hall 2013: 1582-83).

5 Marx's (1976) analysis of primitive accumulation highlights the mechanism of enclosure of land in Britain, involving direct dispossession through the use of state and class power. However, as elaborated below, evidence from India and Bangladesh documents the operation of mechanisms of land appropriation that are not necessarily based on force or directly aimed at grabbing land. Some kinds of mechanism are based on agreement or contract with the pre-existing landholders, involving voluntary processes based on persuasion, incentives or temptation, rather than coercion. Among these are 'marketdriven processes of dispossession' (Akram-Lodhi 2012: 130-31, Hall 2013: 1585).

Significantly, certain theoretical interpretations of primitive accumulation and ABD hold that these processes are necessarily characterized by extra-economic coercion (e.g. Levien 2012, 2013) and/or non-market transactions (e.g. Khan 2004: 77). However, the state itself is a non-market mechanism which uses extra-economic coercion (e.g. land acquisition) in processes of capitalist, rather than primitive, accumulation. Consequently, the distinction between primitive accumulation and capitalist accumulation needs to be pitched in more rigorous and theoretically defensible terms. Moreover, as argued in this paper, defining primitive accumulation/ABD as corresponding to extra-economic or nonmarket processes cannot capture the entire range of mechanisms of land appropriation evidenced in contemporary India and Bangladesh (Sampat 2015: 767 n. 4). In particular, mechanisms that are based on market transactions or do not involve the use of force would be excluded from such definitions and hence would need to be theorized in other ways.

7 Given these considerations, the objective of this article is to develop a comprehensive and logically consistent typology of land alienation mechanisms which could be applied to empirical case studies from contemporary India and Bangladesh. This would provide a comparative assessment of the roles and relative significance of different types of land alienation mechanisms in the specific social-historical conditions of India and Bangladesh in the context of neoliberal globalization.

8 Given constraints of space, it will not be possible to include in this paper an analysis of the politics of land alienation in terms of resistance, repression, negotiation and cooption, nor of ideological contestations about the justification and legitimacy of such acts (e.g. manipulation of discourses of development and security or corporate social 
responsibility). However, these aspects are briefly noted in context wherever possible (and are addressed in other papers in this volume).

The next section (2) provides a critical review of the theoretical features of primitive accumulation and $\mathrm{ABD}$, leading to the postulation of a typology of land alienation mechanisms. This analytical framework is then applied to empirical evidence from contemporary India and Bangladesh in Section 3 to trace the detailed operational aspects of the mechanisms of land alienation. Conclusions and insights emerging from the analysis on the comparative aspects of the mechanisms of land alienation are stated in Section 4.

\section{Primitive Accumulation and ABD: Theoretical issues}

The discussion below is guided by the following considerations: First, how can land alienation be interpreted in terms of the theoretical concepts of primitive accumulation and accumulation by dispossession (ABD)? Second, what are the distinctive properties of land and how do these affect the mechanisms of the appropriation of land by one party from another? Third, how can the mechanisms of land alienation be categorized in terms of a typology that can distinguish analytically between the different kinds of mechanisms documented in the empirical studies?

\section{Analytical features of primitive accumulation}

11 The key features defining primitive accumulation as well as distinguishing it from capitalist accumulation are twofold (Marx 1976:873-95; 2010). First, primitive accumulation involves the dispossession of non-capitalist owners or users and their separation from erstwhile lands and inputs, such that these resources become potentially available for deployment in capitalist production. ${ }^{3}$ Second, the accumulative mechanisms of primitive accumulation are analytically distinct from expanded reproduction and centralization of capital, which are components of capitalist accumulation. Expanded reproduction involves deployment of profit (surplus value) into successive cycles of production on an increasing scale. The centralization of capital pertains to transfer of resources (land) between capitalist production units, e.g. when a capitalist firm goes out of business and its assets including land are bought on the market by a surviving firm, or during mergers of capitalist units. Accordingly, while appropriation of the land of a capitalist unit by another corresponds to centralization of capital within the domain of capitalist accumulation, the transfer of lands of non-capitalist producers or institutions to capitalist producers corresponds to primitive accumulation.

The crucial theoretical distinction between primitive and capitalist accumulation therefore lies in differences in the nature of the respective accumulative processes and their potential outcomes. Provided the resources (lands) are transferred from non-capitalist to capitalist units, the varied mechanisms mediating alienation of land noted abovewhether coercive or voluntary, market or non-market, direct or indirect-can be regarded as alternative means of primitive accumulation (Adnan 2013:93-94). This formulation of primitive accumulation goes beyond simply the use of force (extraeconomic coercion) or specific institutional means (non-market transactions), and holds the possibility of incorporating the wide range of land appropriation mechanisms noted in the empirical evidence from neoliberal India and Bangladesh. 
13 Moreover, Marx's (2010:536) notion of primitive accumulation entails not only the quantitative transfer of resources, but also qualitative transformation in the form of property and social-institutional relations. Through the process of separation, different classes come to control (i) the resources to be converted into capital such as land and (ii) 'labour power'. Thus, what is involved is a process of transformation of 'social-property relations' which creates the classes of employers and workers who can potentially come together in capitalist relations of production (Dobb 1963:185-86, Wood 2002:31-37, 2006: 19-20, Brenner 2006: 97-98).

These general features of primitive accumulation require further refinement when the concerned resource is land. As it is non-producible and location-specific, there can be only a fixed stock of land in a given place (Marx 1981: 915-24, Kautsky 1988: 72, 145, Banaji 1976: 17-39, Adnan 1985: 57). This gives rise to a 'zero-sum game' situation in which the acquisition of land by one party necessarily entails an equivalent loss for another. Consequently, when non-capitalist social groups/classes (e.g. peasants) already hold ('preoccupy') a particular plot of land, capitalists wanting to produce in the same location have no option but to acquire it by any possible means, whether by force or otherwise (Kautsky 1988: 146-47, Banaji 1976: 31, Brenner 1977: 74, Hussain \& Tribe 1981: 124-25).

\section{Primitive accumulation as a historically ongoing process}

15 In Marx's writings, the notion of primitive accumulation varies between (i) a one-off event at the 'genesis of capitalism' and (ii) a historically ongoing process that continues to take place over time in different countries and economic sectors. ${ }^{4}$ Even when capitalist producers emerge and co-exist with non-capitalist classes, primitive accumulation does not cease but continues to take place because the reproduction and expansion of capitalist units generates recurrent demand for production inputs (Marx 1976: 912, Hall 2013: 1585). In particular, given fixity in the stock of land, capitalists have no other way of obtaining incremental plots except by appropriating them from the non-capitalist holders (Kautsky 1976, Adnan 1985). Consequently, the very functioning of capitalism drives a continuing process of 'ex novo separation' of land and other resources from classes possessing them in co-existing non-capitalist sectors (De Angelis 2001: 9, 2004: 63$64,77)$.

16 It follows that, once capitalist production has begun, it becomes a critical driver of primitive accumulation in subsequent phases (Perelman 1984, MNC 2001:1-2). However, this does not explain why and how other kinds of primitive accumulation may take place that are not deliberately driven by capitalism, but nonetheless make available resources such as land for potential deployment in capitalist production ( $c f$. Adnan 2013, 2014: 26). To understand how that can happen, it is necessary to identify other kinds of processes through which non-capitalist property rights are undermined and the released elements, particularly land, become available for possible use by capitalist producers. In so far as such processes are not deliberately driven by capitalism or any other force, they correspond to indirect forms of primitive accumulation, leading to the release of land and other resources as unintended consequences. These ideas pertaining to different types of mechanisms of primitive accumulation are fleshed out below with empirical evidence from India and Bangladesh and reiterated in the concluding section. 


\section{Analytical features of Harvey's ABD and critical issues}

17 Harvey's (2005: 144-61) formulation of 'accumulation by dispossession' (ABD) broadens and updates Marx's construct of primitive accumulation by incorporating newer mechanisms emerging in the context of globalized capitalism (MNC 2001:4) and 'neoliberal imperialism' (Brenner 2006: 102, Ashman \& Callinicos 2006: 115-17, Fine 2006: 143-44). The concept highlights the effects of neoliberal policies, including structural adjustment programmes, illustrated by the imposition of devaluation on vulnerable countries by the International Monetary Fund (IMF), the World Bank and powerful capitalist states. Such pressure can result in forced commoditization and privatization of resources leading to drastic reductions in the prices of land and other assets, which can then be 'profitably recycled back into the circulation of capital' (Harvey 2005: 150-56, Hall 2013: 1585-86). Neoliberal globalization also puts private corporations under intense competitive pressure, impelling them to grab land at very low or near-zero costs, e.g. by undermining the social and legal institutions protecting the rights of the pre-existing holders (Harvey 2005: 149, Luxemburg 2003:348-51, Brenner 2006:99, De Angelis 2004: 73-76).

18 The concept of ABD highlights the unprecedented growth and manipulation of the global financial and credit system. Large-scale loss of land and assets can be orchestrated by powerful institutions of finance capital through speculation and fraud, constituting 'the cutting edge of accumulation by dispossession' (Harvey 2005: 142-47, 2006: 142; cf. Moyo et al. 2012: 193). Financialization is a 'key mechanism of ABD' and involves the conversion of appropriated land 'into an object of financial investment and speculation [...] including securitization and the emergence of private equity funds dealing in farmland' as well as 'the deepening financialization of nature' (Hall 2013: 1593-95).

19 In a critique of Harvey, Levien (2012) contends that extra-economic coercion is the defining characteristic of ABD. However, functioning of the 'real estate and financial markets' explicitly incorporates economic mechanisms, over and above extra-economic ones, in the conceptualization of ABD-a point forcefully reiterated by Harvey (2006) in a rejoinder to critics. Also, the notion of ABD has been subject to other criticisms, which are not presently taken up (however, some of them are addressed by Gardner \& Gerharz in this volume). ${ }^{5}$

20 In comparative terms, there are certain differences in the conceptualization and empirical manifestations of primitive accumulation and ABD (Adnan 2013). Moreover, viewed in a long term perspective, the mechanisms and mediating institutions of primitive accumulation have been undergoing change with shifting social-historical circumstances. It is therefore arguable that new mechanisms of primitive accumulation are likely to emerge in the future as the underlying economic, political and social structures continue to change. Given these considerations, I have used the term primitive accumulation below to designate the generic capitalism-facilitating process by which resources from non-capitalist classes become available for capitalist production, cutting across different historical periods (Adnan 2013: 123, 2014: 39). Correspondingly, the term $\mathrm{ABD}$ is used to designate the distinctive forms of primitive accumulation that have arisen in the specific social-historical conditions of neoliberal globalization, as pointed out in context below. 


\section{Mechanisms of Land Alienation}

21 Given monopoly control over land by current holders, voluntary transactions may not always be a feasible option for converting non-capitalist landed property into transactable commodities that can be deployed in capitalist production (Brenner 2006: 9899). Nonetheless, direct use of force-'extra-economic coercion'-is not the only possible means by which land can be made available for capitalist needs (Kautsky 1988: 146-47, Banaji 1976). For instance, imposition of money taxes or unfavourable changes in relative prices can undermine the viability of self-employed producers, constraining them to undertake distress sale of their lands (Perelman 1984: 46-58, Burawoy 1985: 216-19, De Angelis 2004: 78, Deininger 2003: 96-97). Such mechanisms correspond to indirect forms of primitive accumulation, because dispossession is a 'by-product' of processes primarily geared to other objectives. In this sense, processes quite unrelated to those driven by capitalism can lead to land alienation, corresponding to 'negative externalities' (De Angelis 2004: 77-79) or unintended consequences (Adnan 2013: 122, 2014: 26).

Even though a variety of mechanisms are listed illustratively in Marx's (1976) exposition of primitive accumulation and Harvey's (2005) formulation of ABD, neither orders them into a systematic typology. In the discourse on land alienation in South Asia, while the direct role of force or extra-economic coercion has received pre-eminent attention (e.g. Walker 2008), the significance of the indirect role of credit-land (or credit-lease) interlocked market contracts leading to constrained sale of mortgaged lands to settle cumulative debts has also been noted by scholars (Bharadwaj 1974, Bhaduri 1983: 41-2, $85-87,106-07)$. These considerations point to the need for a systematization of the diverse mechanisms of land alienation within a logically consistent typological schema, which can distinguish between forced and voluntary acts as well as direct and indirect structures of causation.

Given these considerations, I propose a typology of land alienation mechanisms based on the combination of two binary divisions: (i) forced and unforced and (ii) direct and indirect. This leads to a fourfold classificatory schema of such mechanisms, represented in Figure 1 below.

\begin{tabular}{|l|l|l|}
\hline Use of Force/ Directness & Direct & Indirect \\
\hline Forced & 1. Direct-Forced & 3. Indirect-Forced \\
\hline Unforced & 2. Direct-Unforced & 4. Indirect-Unforced \\
\hline
\end{tabular}

Figure 1: Typology of mechanisms of land alienation

In the discussion below, I illustrate this typology with empirical evidence from contemporary India and Bangladesh, specifying the details of the particular mechanisms subsumed under the broad categories in each of the quadrants of the figure. 


\section{Mechanisms of Land Appropriation in India and Bangladesh}

\section{Direct mechanisms using force}

A major type of mechanism of land appropriation in contemporary India and Bangladesh corresponds to the category 'Direct-Forced' in the first quadrant of Figure 1. Even when the concerned laws, policies or commands do not involve use of overt violence, they are nonetheless backed by the coercive apparatus of the state or powerful private agencies and individuals.

\section{State-mediated land appropriation}

The most well-known institutional framework for attracting foreign and domestic investment within a delimited territorial location has taken the form of 'special zones' of various kinds for particular projects, set up by the state. In India, these were termed Special Economic Zones (SEZ), with the stated purpose of providing 'incentives for the private sector to invest in the creation of world-class infrastructure' including 'tax concessions and regulatory exemptions' (Jenkins 2014: 39, Sampat 2015: 766). Such Zones constituted 'hyperliberalized economic enclaves' aimed at 'promoting exports, attracting FDI, developing infrastructure, and generating employment' (Levien 2012: 934).

In Bangladesh, comparable enclaves were established with a variety of designations, including Export Processing Zones (EPZ), Economic Zones (EZ), Shrimp Zones and investor-specific enclaves such as the Korean EPZ in Chittagong. State acquisition of land has also taken place for standalone projects of private multinational corporations, e.g. in the case of the Bibiyana gas-field in the Sylhet district of Bangladesh operated by Chevron (Gardner 2012: 87, Gardner et al. 2014: \$5-7, Ahasan \& Gardner in this volume). In the Chittagong Hill Tracts (CHT) of Bangladesh, the state forcibly acquired the private and common lands of the indigenous peoples and leased these mostly to absentee Bengali elites for raising commercial plantations (Roy 1995, Mohsin 1997).

The territorial dimension of these various special zones and projects made land acquisition an integral element of setting them up (Levien 2012). In both India and Bangladesh, government agencies signed contracts with private domestic and foreign corporations which transferred large tracts of land and mineral rights to them on highly concessionary terms (Walker 2008, Bharadwaj 2009, Jenkins et al. 2014, Sampat 2015). This applied to the 'special zones' as well as standalone projects for purposes such as mining, commercial farming, physical infrastructure and economic development in general. However, the specific terms and conditions of the land concessions given to the various individual zones and projects varied due to policy differences, local politics, commodityspecific requirements, etc. (Jenkins 2014, Vijayabaskar 2014).

In India, regulatory changes led to successive shifts in the minimal proportion of a SEZ's territory that had to be devoted to the 'processing area' concerned with 'export-oriented activities'. This was eventually raised to 50\% of the total area in 2007 (Jenkins 2014: 4647). The remainder of SEZ areas were thus left free by policy design, and were usually utilized for building profitable commercial facilities catering to upper and middle class 'life-styles', e.g. residential complexes, shopping malls, hotels, golf-courses, and tourist 
resorts (Walker 2008: 588-89, Levien 2012: 934, Jenkins 2014: 48). Such patterns of land use frequently gave rise to thriving financial speculation in real estate in and around these special zones and project areas, particularly in sites close to major urban centres (Sampat 2008, Das in this volume). In Bangladesh, a proportion of grabbed lands in the Noakhali Shrimp Zone and the Chittagong Hill Tracts was deployed for speculation in real estate (Adnan 2013, 2014, Adnan \& Dastidar 2011). Such connections between land grabs and financial speculation correspond to Harvey's (2005: 158) conception of ABD.

The forcible appropriation of land involved dispossession of the erstwhile inhabitants by invoking the respective state acquisition laws operating in India and Bangladesh. Despite variations, this genre of laws contained sweeping provisions based on the legal principle of eminent domain, which empowered the state to acquire private land for public purposes, overriding objections by those dispossessed in the process (Vasudevan 2008: 41, Benjamin 2000: 38). For example, in the CHT of Bangladesh, a particularly draconian law ${ }^{6}$ has been used that empowers the state to use force for acquiring land without having to give prior notice or providing the right of appeal to the dispossessed landholders (Adnan \& Dastidar 2011: 45-46).

In India, the archaic Land Acquisition Act (LAA) of 1894 has been widely used for this purpose, inclusive of procuring land for SEZs (Walker 2008: 589). The law had been subject to widespread criticism for inefficient, corrupt and inequitable outcomes, as well as the 'insufficiency of the protections for land-owners' (Jenkins 2014: 56). In 2007, an official decision was taken which 'prohibited state governments from using the LAA to compulsorily acquire land for SEZs. This went to the heart of the land issue, addressing [... ] the appropriateness of forcibly acquiring land for SEZs at all' (Jenkins 2014: 48-49). These developments created the grounds for drafting a new law, termed the Land Acquisition, Rehabilitation, and Resettlement Bill (LARRB) 2011, which was enacted in 2013 (Jenkins 2014: 55).

Moreover, not all those evicted and displaced by state acquisition of land have been adequately compensated and/or rehabilitated by the concerned authorities. Typically, only those with formal land rights or titles were recognized as being eligible, while all those whose livelihoods depended upon common or customary 'rights of use' on open access lands and water bodies were denied compensation and rehabilitation (Walker 2008: 582-90; Gardner 2012, Banerjee 2014: 276-77). Even when compensation was paid, the acquired lands were usually valued well below open market prices (see Das in this volume). In such cases, the state would be in a position to acquire lands at cheap prices and then sell or lease them to private investors at much higher rates (Levien 2012: 94748, Walker 2008:582-89, Banerjee 2014:277). As specified above, such practices of undervaluing resources to enable them to be acquired at rock bottom prices are characteristic of ABD in the context of neoliberal globalization (Harvey 2005: 149-50).

In practice, the laws and procedures of state acquisition, compensation and rehabilitation were flouted in varying degrees. Even though government departments and security forces are required by law to follow formal land acquisition procedures, there are instances where they have taken over the territories of relatively powerless and politically weak social groups by using illegal force and fraudulent means, violating the very laws and property rights that they were supposed to uphold (Adnan \& Dastidar 2011: 45-60, Banerjee 2014: 295, Feldman in this volume). In India, the West Bengal state government ignored its own land use policy when agreeing to transfer agricultural lands to a major 'Indian multinational' for constructing a 
car factory in Singur (Basu 2007: 1283). It also failed to pay due compensation and provide the land titles promised to resettled families in Falta SEZ (Banerjee 2014: 279). The Hyderabad Urban Development Authority disregarded the Urban Land Ceiling Act in order to give retroactive legal sanction to illegal encroachments by powerful groups (Whitehead 2012: 32).

Furthermore, the legal-institutional rules and procedures that had formerly protected the land rights and entitlements of vulnerable groups were repealed, along with the promulgation of new laws and policies that facilitated corporate interests in getting hold of land and natural resources (Sebastian 2012:10, Walker 2008: 590, Bharadwaj 2009). Promulgation of the National Mining Policy and the Unlawful Activities (Prevention) Act, 2008, provide instances of new rules and policies facilitating state-led land grabs in India. Existing constitutional provisions and laws protecting adivasi rights were dismantled or ignored by the state in order to enable private corporations to gain access to forests, minerals and other resources. For instance, the Chhattisgarh Public Security Act of 2005 was used to evict tribal groups in order to take over their mineral-rich lands for subsequent allotment to private corporations (Walker 2008:558). Restrictions on acquisition of tribal lands without the consent of the concerned communities, stipulated in the $\operatorname{PESA}^{7}$ (1996) Act, were often circumvented by illegal means (Bhaduri 2008: 13).

What is noteworthy about the current neoliberal period is that not only is land being acquired by the state for transfer to private corporations, but also that it is being justified under the pretext of 'public purpose'. In these instances, the state has served as 'land broker' par excellence for profit-making private corporations and commercial agencies (Bhaduri 2008, Walker 2008: 580, Levien 2012: 941-46). Such practices have been deeply unpopular, contributing to the erosion of the legitimacy of the state as an agent of development during the neoliberal era.

\section{Land appropriation by non-state agencies}

37 A wide range of non-state agencies have also been significantly involved in land appropriation in contemporary India and Bangladesh. These include private corporations and business houses, political party organizations, 'commercial NGOs', powerful individuals and interest groups, as well as organized mafia and criminal gangs (Benjamin 2000: 47).

Case studies of land appropriation in India 'highlight a key trend: the use of officially sanctioned criminal violence at the level of the state and by private landholders against the rural poor' (Walker 2008: 559, 591-93). In the SEZs of Chhattisgarh and the aborted SEZ in Nandigram, West Bengal, security forces of the state were joined by cadres of the respective ruling parties or criminal thugs in operations to crush the resistance of dispossessed groups (Nigam 2007: 6-7, Banerjee 2014: 282-83, 293-97). In the case of the POSCO SEZ in Odisha, 'forces funded and instigated by the [private] SEZ developer allegedly led the crackdown on local expressions of dissent' by protesters (Banerjee 2014: 293-94).

In Bangladesh, non-state agencies including private corporations, 'commercial NGOs', influential elite groups and political party leaders have been using violence by hired gangs to grab lands of weaker social groups and ethnic minorities (Feldman \& Geisler 2012: 982, Adnan \& Dastidar 2011: 86-94). Case studies of land grabs by multinational corporations extracting gas and minerals in Bangladesh indicate that they follow double- 
edged strategies that attempt to show a 'smiling face' while manipulating techniques of corporate social responsibility (CSR), public relations (PR) and 'partnerships' with local communities and reputable NGOs to rebrand themselves (Ahasan \& Gardner in this volume). One multinational distanced itself from the unpopular task of land acquisition by delegating it to the administrative agencies of the state, while gaining from the process and facilitating it with higher rates of compensation and faster procedures of implementation (Gardner 2012).

\section{Direct mechanisms without the use of force}

The mechanisms in this category involved the direct appropriation of land without the use of force or violence (corresponding to the category 'Direct-Unforced' in quadrant 2 of the typology in Figure 1). Instead, other methods such as informal mediation, negotiations, persuasion, temptation, fraud, or forgery were used to orchestrate transfer of the lands, often through manipulation of the state and/or the market.

41 A remarkable instance of this mode of direct land acquisition with the use of relatively little coercion can be found in the Indian state of Tamil Nadu. Vijayabaskar (2014: 305) notes that compared to other states, there was very little organized resistance to the procurement of land for SEZs in this state, resulting in what he terms 'the politics of silence'. One of the key factors underlying this outcome was a set of conscious 'strategies deployed to curb resistance' by the Tamil Nadu government, inclusive of 'market mechanisms, facilitating negotiations between landowners and private firms' (Vijayabaskar 2014: 306). As early as 1995, a Government Order (GO) established official committees that were empowered to acquire lands through private negotiations rather than the state acquisition law (LAA) (Vijayabaskar 2014:313). Further scope for the operation of market-based pricing systems and streamlining the acquisition of land was formalized through conducive legislation-the Tamil Nadu Acquisition of Land for Industrial Purposes Act (TNALIPA) of 1999 (Vijayabaskar 2014: 313-14).

Moreover, substantive material incentives were offered to those who agreed to give up their land without fuss. In some cases, land acquisition was linked to provision of alternative land and new jobs as part of a package deal. 'Housing plots in a planned residential zone would be provided to owners who sold their land, the size of the plots based on the amount of land sold' (Vijayabaskar 2014:320). The state finance minister promised 'at least one job to each family that cedes an acre or more of land for an SEZ's establishment' as well as training facilities to equip such persons with requisite skills (Vijayabaskar 2014: 316).

43 Another instance of this kind of package deal to obtain land for the Mahindra World City SEZ in Rajasthan in India involved the use of material incentives to persuade landholders not to oppose the acquisition of their lands. The affected landowners were offered smaller but high-value developed commercial and residential plots in exchange for their acquired holdings, which effectively served to 'buy peace' by dissuading them from resisting land acquisition (Levien 2012: 953).

In the case of the Perambalur multi-product SEZ in Tamil Nadu, farmers are reported to have decided en masse to sell their land voluntarily 'when the prices offered were much higher than anticipated', exceeding the prevailing market price (Vijayabaskar 2014: 320). Similarly, in Bangladesh, opposition to the Bibiyana Gas Field began to dissipate when 
land owners were offered higher rates of compensation and promises of contracts by the land-acquiring corporation (Ahasan \& Gardner in this volume).

Comparable techniques of appropriating land and water resources were based on sheer market bargaining power and/or technological superiority, reflective of direct mechanisms of primitive accumulation without the use of force and violence. For instance, municipal authorities in Bangalore acquired areas in IT corridors through 'etitling and GIS planning' in ways that simply 'erased' from the city's land records the erstwhile customary rights of local landholders (Whitehead 2012:32). Correlatively, private corporations producing soft drinks in India extracted 'pure groundwater as a free raw material' from great depths using expensive capital-intensive technology that could not be matched by local peasant agriculturalists (Bhaduri 2008: 13, cf. Walker 2008: 564$65)$.

\section{Indirect mechanisms backed by force}

This category applies to mechanisms of land appropriation that are indirect, but backed by public or private force (and corresponds to the label 'Indirect-Forced' in quadrant 3 of the typology in Figure 1). These are not driven with the direct objective of land appropriation by capitalism or any other factor. Nonetheless, their outcomes are comparable to those of enclosure, working indirectly through processes triggered by policy and development interventions or autonomous factors that are primarily concerned with other objectives.

47 The operation of this type of indirect mechanism is illustrated by the consequences of setting up the Noakhali Shrimp Zone in Bangladesh with the avowed objective of promoting shrimp production for the export market (cf. Adnan 2013:117-22). Paradoxically, establishment of the Zone did not lead to the realization of this intended objective. Instead, it raised land values in the area and triggered violent repression and land-grabbing by state agencies and private interest groups among dominant classes, which resulted in the mass eviction of the poor peasantry. In this instance, primitive accumulation was the indirect outcome of mechanisms activated by neoliberal policies and development interventions concerned with very different objectives (e.g. setting up an export-oriented shrimp zone).

The operation of such processes on a wider scale is illustrated by the impacts of the neoliberal policies followed by the government of India, which led to the restructuring of agricultural production. Among these policies were fiscal contraction and other measures deflating income and reducing support to agriculture and the entitlements of the poor (Patnaik 2008: 109, 2012:35-37, U. Patnaik 2012:249, Shah 2008: 80). Apart from impoverishing peasant producers in the short term, the cumulative impacts of these neoliberal policies also undermined their long term viability (Patnaik 2008: 113). As a result, peasant production units faced collapse when they could no longer afford to purchase necessary inputs, eventually leading to the sale of their lands and other resources.

49 The implementation of such neoliberal policies and development projects was clearly backed by state power, even if the state did not always apply overt violence. Moreover, such policies and project interventions were often promoted by international donor agencies and regulatory organizations, including the IMF, World Bank and WTO (Walker 2008:573-74). Since the primary objectives of these nationally and internationally 
generated policy interventions were quite different from the capture of land per se, outcomes involving land alienation constituted unintended consequences, corresponding to indirect forms of land appropriation and primitive accumulation.

Accounts of land alienation frequently include instances of molestation, rape and sexual violence on women of the targetted communities. Such acts have been perpetrated by security forces and officially-mobilized vigilantes and criminal gangs in the SEZs and peasant villages of India (e.g. Chhattisgarh and West Bengal) (Walker 2008: 590, 599-605, Nigam 2007: 7), as well as various parts of Bangladesh (Feldman in this volume). These acts were frequently undertaken with the ulterior motive of grabbing land by targeting women in order to demoralize their entire communities, thereby pressurizing them to move out or give up their resistance (Walker 2008, Mohsin 1997: 178, Adnan \& Dastidar 2011: 96-97). Such tactics reflect the use of complex and multifaceted mechanisms of land appropriation which operated indirectly through human rights violation aimed at women of the targeted social groups and communities.

51 It is, of course, quite possible that those initiating such indirect policies and interventions were not entirely unaware that land alienation would be a possible outcome-even if that was not explicitly declared as the objective. In this sense, the actual 'degree of intentionality' behind such acts and policies may remain somewhat uncertain and ambiguous.

\section{Indirect mechanisms without use of force}

This category of mechanisms neither involved the use of force, nor was directly concerned with appropriating land, even though the eventual outcomes led to such dispossession (corresponding to the label 'Indirect-Unforced' in quadrant 4 of Figure 1). As with the previous category, these mechanisms are not directly driven by capitalism or other forces with the explicit objective of land appropriation.

This type of mechanism is illustrated by the eventual sale of mortgaged land (collateral) to settle outstanding debt, noted above (Bhaduri 1983, Bharadwaj 1974). The borrower enters the credit-land interlocked market transaction, requiring mortgaging of land as collateral, but there is no intent to sell. However, the cumulative build-up of the principal and interest can eventually constrain the borrower to settle the outstanding debt through 'distress sale' of the mortgaged land. This credit-based mechanism does not involve external coercion, nor is it directed at land alienation in the first instance; nonetheless the outcome in terms of land loss is similar to that of direct dispossession.

Hall (2013: 1591-92) regards this as one of the basic means by which land alienation takes place: 'people who cannot keep their heads above water as farmers take on more and more debt and, eventually, have to sell their land to survive. Such 'economic' or 'market sales' are 'voluntary' in the sense that people are not coerced or legally obliged to sell to any particular party or at any particular price'. It is, of course, possible that the initial decision to enter the loan contract was a constrained choice, e.g. neoliberal agricultural policies had undermined the viability of the peasant production unit, impelling it into debt. In such instances, this would constitute an indirect mechanism which is partly driven by exogenous forces (see the next section for further elaboration of combinations of multiple mechanisms). 
55 A more general formulation of this broad category applies to varied instances in which pre-existing forms of production have been undermined by factors that are not deliberately aimed at such outcomes, but nonetheless lead to the separation of the erstwhile landholders or producers from their lands. For instance, agricultural production can be undermined by a whole range of factors that are not directly aimed at land alienation, nor involve the use of force, such as rising market costs of production, defective water control structures leading to waterlogging, ecological degradation resulting from the advent of new technology, adverse impacts of climate change and saline inundation, etc. Such a process is illustrated by Mishra's (2011:3) account of 'dispossession in slow motion' in the Indian state of Odisha, which has 'involved 'voluntary' transfers of land over longer time periods in which the pincer movements of rising production costs, indebtedness, and neoliberal policy have led to agrarian crisis and the longer term movement of the rural poor from their land' (Gardner \& Gerharz in this volume). Correlatively, in Dhaka city in Bangladesh, the filling up of wetlands due to environmental pollution and illegal constructions as well as the blockage of water channels have forced people to abandon or sell their land (Gardner \& Gerharz in this volume).

Another instance of this kind of mechanism is provided by ongoing socio-economic, political and legal changes that bring about situations of legal pluralism and multiple titling, creating the ground for potential land loss. The sequential 'stacking of laws' and customary rights can lead to the co-existence of multiple de jure and/or de facto rights on the same plot, making conflicts about land endemic (cf. Jansen \& Roquas 1998: 83-85, 9294, Assies 2007: 12). Such 'ambiguous' lands (Sato 2000) with unclear titles have been particularly susceptible to expropriation because the fuzziness in their legal status provided scope for manipulation and expropriation by powerful agencies (Benjamin 2008: 725, Adnan 2013: 100, Banerjee 2014: 291-92).

For instance, the system of landed property in the CHT became highly complex and multilayered with overlapping rights, following the emergence of pockets of private property in the context of pre-existing state lands and common property under customary rights (Roy 1995, Mohsin 1997). While the prevalent laws acknowledged and codified some of the customary common rights of the indigenous peoples, there were 'grey' areas which remained undefined, even when such lands were used by the locals for everyday livelihood needs (Roy 1995). In many cases, (i) individual households, (ii) the village community, and (iii) the state could simultaneously hold distinct rights over the same land. Such coexistences of partially overlapping state, common and private land rights was symptomatic of a situation of legal pluralism and multiple titling in the CHT. The resultant ambiguity (Sato 2000) in the status of these lands provided the basis of subsequent appropriation through more direct mechanisms. Accordingly, loss of land by the indigenous peoples of the CHT was partly the 'unintended consequence' of endemic contestations resulting from the plurality of legal systems and multiple land claims by contending parties.

58 In certain circumstances, it may be difficult to distinguish between the outcomes of indirect mechanisms that use force and those that do not. For example, this applies to the experience of the indigenous peoples in the CHT where extra-economic coercion by security forces resulting in violation of human rights (as contrasted to direct land grabbing) operated in parallel with the more diffuse long term processes generating legal pluralism and multiple titling, jointly leading to alienation of their lands. 


\section{Combination of multiple mechanisms}

While the exposition above has considered individual categories of land alienation mechanisms, in reality these do not necessarily operate in isolation. The experiences of India and Bangladesh provide instances in which the structure of causation underlying land alienation involved several different mechanisms operating in combination, as follows.

Constrained sale of land by agricultural producers for settling cumulative debts have sometimes been the eventual outcome of income deflation triggered by neoliberal measures such as structural adjustment programmes advocated by the World Bank and IMF. Such a 'distress sale' (Deininger 2003: 96-97, Fortin 2005: 164) in the market thus constituted only the terminal link in an extended chain of causation driven by antecedent variables, ranging from global institutional pressures to state policies, violence and intimidation, legal harassment through false litigation, etc.

61 In the Bibiyana gas-field in Bangladesh, the acquisition of land was made feasible by the combination of several direct and indirect mechanisms and involved the use of force as well as the (deceptive) tactics of negotiation and making promises (Ahasan \& Gardner in this volume). The specific factors included state acquisition of land, steps taken by the local administration which deployed security forces against protesters and intimidated those unwilling to give up their lands, raising of the compensation rates by Chevron through direct negotiations, as well as (false) verbal assurances of hope to the dispossessed villagers in terms of including them in development and modernization programmes (Gardner 2012: 87-90).

The use of multiple mechanisms of land alienation is also evident in the continuing takeover of the land and property of the minority Hindu communities of Bangladesh by the state and powerful elite groups. Specifically, this has involved invocation of the sceptre of 'enemy property', constructed through the Vested Property Act and a series of discriminatory state laws, social and cultural 'rhetorics of othering', as well as exclusionary practices by bureaucrats, political leaders and power holders (Feldman in this volume). Security forces such as the military have systematically expropriated lands of Hindus and other religious and ethnic minorities in different parts of Bangladesh on the pretext of ensuring 'national security' (Adnan \& Dastidar 2011; Gardner \& Gerharz in this volume). Such 'slow motion' land grabs, through which members of various ethnic and religious minorities have lost much of their erstwhile property, even while continuing to stay in their original homesteads, corresponds to the notion of in situ dispossession put forward by Feldman \& Geisler (2012, cf. Mishra 2011).

In Tamil Nadu, land alienation has to some extent been propelled by the joint operation of voluntary market transactions and decisions made under threats of coercive state action. Thus, '[p]rivate firms have long acquired land through market transactions for the development of plantations and other purpose' and such

'reliance on the market may seem to indicate that land acquisition in Tamil Nadu is accomplished more through consent than coercion. Still, [...] the veiled threat of compulsory takeover by government, non-recognition of interests in land due to lack of clear title, and the takeover of 'wastelands' and 'dry' lands using misleading classificatory systems-all reflect the power of the state backed by privileged interests' (Vijayabaskar 2014: 326). 

theoretical implications. As compared to the pre-eminent role of 'enclosure' in Marx's analysis of primitive accumulation, involving deliberate and forcible dispossession, the 
evidence on land appropriation in India and Bangladesh shows the operation of additional mechanisms with distinct features. While the range, diversity and complexities of the mechanisms of land alienation have been demonstrated above, the causal processes underlying them can be ordered into a few major patterns in terms of the typology put forward earlier.

On the one hand, there are clear instances of deliberate and forcible expropriation of land by the state and private interest groups. On the other hand, comparable outcomes have resulted indirectly from the working out of complex processes triggered by autonomous factors, including policy and development interventions that were primarily concerned with other objectives (cf. Adnan 2013: 122).

As noted in the discussion of direct mechanisms (quadrants 1 and 2 of the typology), capitalist production itself has been a force undertaking land appropriation through the deliberate dispossession of politically weak groups such as peasants and indigenous peoples. Viewed from this perspective, 'actually existing capitalism' has been directly expropriating stocks of land via primitive accumulation (in addition to the appropriation of flows of surplus value or profit by employing wage workers ) (cf. Marx 1976: 912, Adnan 2014: 40). In these instances, the structure of causation is one in which the needs of capitalist production drives primitive accumulation in the form of direct land appropriation.

71 However, not all mechanisms of land alienation have been deliberately driven by capitalist production or necessarily aimed at procuring its inputs. This consideration applies pre-eminently to the indirect mechanisms (quadrants 3 and 4 of the typology), such as neoliberal policies and development interventions as well as autonomous social, economic, demographic and environmental processes that were not directed at the dispossession of non-capitalist landholders but nonetheless led to such outcomes. To the extent that the lands released by these processes were subsequently deployed in capitalist production, such outcomes were 'by-products' or unintended consequences of these indirect mechanisms (Adnan 2014: 40). In these instances, the structure of causation is one in which primitive accumulation processes generated by autonomous factors lead to the release of land for potential deployment in capitalist production.

These two diametrically opposite structures of causation correspond to the direct and indirect mechanisms of land alienation, designated respectively by quadrants 1-2 and 3-4 in the typology postulated above. They also serve to provide a logical closure to the questions raised earlier about the differences between the mechanisms of primitive accumulation that are, or are not, deliberately driven by capitalism and other forces.

The evidence from contemporary India and Bangladesh cited above indicates that there are land alienation mechanisms corresponding to each of the categories in the fourfold typology presented in Figure 1. Moreover, each of these broad headings can be broken down into more detailed sub-types. In this sense, the $2 \times 2$ typological schema of mechanisms of land alienation proposed here is relatively simple. It provides a first approximation in the attempt to order and categorize the numerous specific mechanisms, which can be further elaborated as necessary. Correlatively, more complex mechanisms of land alienation can be viewed as combinations of the various individual categories posited above, operating through an extended chain of causation and subject to the possible influence of political forces. 
74 In sum, many different mechanisms of land alienation, mediating primitive accumulation/ABD, have been at work in neoliberal India and Bangladesh. These range from direct land acquisition for a variety of special zones and standalone projects to income deflation induced by neoliberal policies and adverse impacts of development interventions, leading to indirect forms of land loss. Taken together, these varied mechanisms constitute a diverse repertoire from which alternative options and strategies for land grabs and primitive accumulation/ABD have emerged under particular circumstances (cf. Peluso 1992, Burawoy 1985: 214-19, Harvey 2006: 159, Tilly 1978: 15158, Adnan 2013, 2014: 37).

As argued above, mechanisms of primitive accumulation/ABD are not confined solely to the use of extra-economic coercion or non-market transactions. Definitions based on such conditionalities are unduly restrictive because of their focus on only particular traits (e.g. force) and mediating institutions (e.g. non-market agencies), and correspond to special cases. Consequently, these formulations of primitive accumulation/ABD are unable to accommodate the entire range of mechanisms of land alienation that have been empirically observed in neoliberal India and Bangladesh.

\section{BIBLIOGRAPHY}

Adnan, Shapan (1985) ‘Classical and Contemporary Approaches to Agrarian Capitalism', Economic and Political Weekly, 20(30), pp. PE-53-64.

Adnan, Shapan (2004) Migration, Land Alienation and Ethnic Conflict: Causes of Poverty in the Chittagong Hill Tracts of Bangladesh, Dhaka: Research and Advisory Services.

Adnan, Shapan (2013) 'Land Grabs and Primitive Accumulation in Deltaic Bangladesh: Interactions Between Neoliberal Globalization, State Interventions, Power Relations and Peasant Resistance', Journal of Peasant Studies, 40(1), pp. 87-128.

Adnan, Shapan (2014) 'Primitive Accumulation and the "Transition to Capitalism" in Neoliberal India: Mechanisms, Resistance, and the Persistence of Self-Employed Labour', in Barbara HarrissWhite \& Judith Heyer (eds.), Indian Capitalism in Development, London: Routledge, pp. 23-45.

Adnan, Shapan; Dastidar, Ranajit (2011) Alienation of the Lands of Indigenous Peoples of the Chittagong Hill Tracts of Bangladesh, Dhaka: Chittagong Hill Tracts Commission \& Copenhagen: International Work Group for Indigenous Affairs (IWGIA).

Akram-Lodhi, Haroon (2012) 'Contextualizing Land Grabbing: Contemporary Land Deals, the Global Subsistence Crisis and the World Food System', Canadian Journal of Development Studies, 33 (2), pp. 119-42.

Ashman, Sam; Callinicos, Alex (2006) 'Capital Accumulation and the State System: Assessing David Harvey's The New Imperialism', Historical Materialism, 14(4), pp. 107-31.

Assies, Willem (2007) The Theoretical Debate: Paradigms, Concepts, Complex Realities and Dynamics, Holston, (mimeo). 
Banaji, Jairus (1976) ‘Summary of Selected Parts of Kautsky's The Agrarian Question', Economy and Society, 5(1), pp. 1-49.

Banerjee, Partha Sarathi (2014) 'Orissa and West Bengal: The SEZ Imbroglio', in Rob Jenkins, Loraine Kennedy \& Partha Mukhopadhyay (eds.), Power, Policy and Protest: The Politics of India's Special Economic Zones, New Delhi: Oxford University Press, pp. 273-304.

Basu, Pranab Kanti (2007) 'Political Economy of Land Grab', Economic and Political Weekly, 42(14), pp. 1281-87.

Benjamin, Solomon (2000) ‘Governance, Economic Settings and Poverty in Bangalore’, Environment \& Urbanization, 12(1), pp. 35-56.

Benjamin, Solomon (2008) 'Occupancy Urbanism: Radicalizing Politics and Economy beyond Policy and Programs', International Journal of Urban and Regional Research, 32(3), pp. 719-29.

Bhaduri, Amit (2008) 'Predatory Growth', Economic and Political Weekly, 43(16), pp. 10-14.

Bhaduri, Amit (1983) The Economic Structure of Backward Agriculture, London: Academic Press. Bharadwaj, Krishna (1974) Production Conditions in Indian Agriculture, Cambridge: Cambridge University Press.

Bharadwaj, Sudha (2009) 'Gravest Displacement, Bravest Resistance: The Struggle of Adivasis of Bastar, Chhattisgarh against Imperialist Corporate Landgrab', Sanhati, 1 June, pp. 1-39, URL: http://sanhati.com/excerpted/1545/

Brenner, Robert (1977) 'The Origins of Capitalist Development: A Critique of Neo-Smithian Marxism', New Left Review, 104, pp. 30-75.

Brenner, Robert (2006) 'What Is, and What Is Not, Imperialism?', Historical Materialism, 14(4), pp. 79-105.

Burawoy, Michael (1985) The Politics of Production: Factory Regimes under Capitalism and Socialism, London: Verso, New Left Books.

De Angelis, Massimo (2001) 'Marx and Primitive Accumulation: The Continuous Character of Capital's "Enclosures"', The Commoner, 2, September, URL: http://

www.commoner.org.uk/01deangelis.pdf

De Angelis, Massimo (2004) 'Separating the Doing and the Deed: Capital and the Continuous Character of Enclosures', Historical Materialism, 12(2), pp. 57-87.

Deininger, Klaus (2003) Land Policies for Growth and Poverty Reduction, Washington, DC: The World Bank.

Dobb, Maurice (1963) Studies in the Development of Capitalism, London: Routledge \& Kegan Paul.

Feldman, Shelley; Geisler, Charles (2012) 'Land Expropriation and Displacement in Bangladesh', Journal of Peasant Studies, 39(3-4), pp. 971-93.

Fine, Ben (2006) 'Debating the “New” Imperialism', Historical Materialism, 14(4), pp. 133-56.

Fortin, Elizabeth (2005) 'Reforming Land Rights: The World Bank and the Globalization of Agriculture', Social \& Legal Studies, 14(2), pp. 147-77.

Gardner, Katy (2012) Discordant Development: Global Capitalism and the Struggle for Connection in Bangladesh, London: Pluto Press. 
Gardner, Katy; Ahmed, Zahir; Rana, Mohammad Masud; Bashar, Fatema (2014) 'Field of Dreams: Imagining Development and Un-Development at a Gas Field in Sylhet', Samaj, 9, URL: http:// samaj.revues.org/3741

Hall, Derek (2013) 'Primitive Accumulation, Accumulation by Dispossession and the Global Land Grab', Third World Quarterly, (34)9, pp.1582-1604.

Harvey, David (2005) The New Imperialism, Oxford: Oxford University Press.

Harvey, David (2006) ‘Comment on Commentaries', Historical Materialism, 14(4), pp. 157-66.

Hussain, Athar; Tribe, Keith (1981) Marxism and the Agrarian Question, Vol. 1: German Social Democracy and the Peasantry 1890-1907, London: Macmillan.

Jansen, Kees; Roquas, Esther (1998) 'Modernizing Insecurity: The Land Titling Project in Honduras', Development and Change, 29, pp. 81-106.

Jenkins, Rob (2014), 'India's SEZ Policy: The Political Implications of “Permanent Reform”', in Rob Jenkins, Loraine Kennedy \& Partha Mukhopadhyay (eds.), Power, Policy and Protest: The Politics of India's Special Economic Zones, New Delhi: Oxford University Press, pp. 40-70.

Jenkins, Rob; Kennedy, Loraine; Mukhopadhyay, Partha (eds.) (2014), Power, Policy and Protest: The Politics of India's Special Economic Zones, New Delhi: Oxford University Press.

Kautsky, Karl (1988) The Agrarian Question (Vols. 1-2), London \& Winchester (Massachussets): Zwan Publications.

Khan, Mushtaq H. (2004) 'Power, Property Rights and the Issue of Land Reform: A General Case Illustrated with Reference to Bangladesh', Journal of Agrarian Change, 4(1-2), pp. 73-106.

Levien, Michael (2012) 'The Land Question: Special Economic Zones and the Political Economy of Dispossession in India', Journal of Peasant Studies, 39(3-4), pp. 933-69.

Levien, Michael (2013) 'Regimes of Dispossession: From Steel Towns to Special Economic Zones', Development and Change, (44)2, pp. 381-407.

Luxemburg, Rosa (2003) The Accumulation of Capital, London \& New York: Routledge.

Marx, Karl (1976) Capital: A Critique of Political Economy (Vol. 1) (Ben Fowkes, Trans.), London: Penguin.

Marx, Karl (1981) Capital: A Critique of Political Economy (Vol. 3), London: Penguin.

Marx, Karl (2010) Capital: A Critique of Political Economy (Vol. 1) (Progress Publishers, Moscow, Trans.), Moscow: Progress Publishers.

Mishra, Deepak K. (2011) ‘Behind Dispossession: State, Land Grabbing and Agrarian Change in Rural Orissa', paper presented at the international conference on Global Land Grabbing, University of Sussex, 06-08/04/2011.

MNC (Midnight Notes Collective) (2001) ‘The New Enclosures', The Commoner, 2, September, (Reprinted from Midnight Notes, 10, 1990).

Mohsin, Amena (1997) The Politics of Nationalism: The Case of the Chittagong Hill Tracts, Bangladesh, Dhaka: University Press Limited.

Moyo, Sam; Yeros, Paris; Jha, Praveen (2012) 'Imperialism and Primitive Accumulation: Notes on the New Scramble for Africa', Agrarian South: Journal of Political Economy, 1(2), pp. 181-203.

Nielsen, Kenneth Bo (2010) 'Contesting India's Development? Industrialization, Land Acquisition and Protest in West Bengal', Forum for Development Studies, 37(2), pp. 145-70. 
Nigam, Aditya (2007) NAPM Report: To Nandigram via Singur: A Preliminary Report on the Struggle and Violence in Nandigram, URL: http://kafila.org/2007/02/27/napm-report-to-nandigram-via-singur/ Patnaik, Prabhat (2008) 'The Accumulation Process in the Period of Globalisation', Economic and Political Weekly, 43(26-27), pp. 108-13.

Patnaik, Prabhat (2012) 'The Peasant Question and Contemporary Capitalism: Some Reflections with Reference to India', Agrarian South: Journal of Political Economy, 1(1), pp. 27-42.

Patnaik, Utsa (2012) 'Some Aspects of the Contemporary Agrarian Question', Agrarian South: Journal of Political Economy, 1(3), pp. 233-54.

Peluso, Nancy L. (1992) Rich Forests, Poor People: Resource Control and Resistance in Java, Berkeley: University of California Press.

Perelman, Michael (1984) Classical Political Economy: Primitive Accumulation and the Social Division of Labour, Totowa, New Jersey: Rowman \& Allanheld.

Roy, Raja Devasish (1995) 'Land Rights, Land Use and Indigenous Peoples in the CHT', in Philip Gain (ed.), Bangladesh: Land, Forest and Forest People, Dhaka: Society for Environment and Human Development (SEHD).

Sampat, Preeti (2008) 'Special Economic Zones in India', Economic and Political Weekly, 43(28), pp. 25-9.

Sampat, Preeti (2015) 'The 'Goan Impasse': Land Rights and Resistance to SEZs in Goa, India', Journal of Peasant Studies, 42(3-4), pp. 765-90.

Sato, Jin (2000) 'People in Between: Conversion and Conservation of Forest Lands in Thailand', Development and Change, 31(1), pp. 155-77.

Sebastian, Gilbert (2012) 'The Big U-turn: New Forms of Primitive Accumulation and the Shift in Patriotic Sensibilities in India', paper presented at an all-India seminar on Parliamentary Democracy and Neoliberalism in India, University College, Thiruvananthapuram (mimeo), 18$19 / 10 / 2012$.

Shah, Mihir (2008) 'Structures of Power in Indian Society: A Response', Economic and Political Weekly, 43(46), pp. 78-83.

Tilly, Charles (1978) From Mobilization to Revolution, Reading (Massachusetts): Addison-Wesley Publishing Company.

Vasudevan, Ramaa (2008) 'Accumulation by Dispossession in India', Economic and Political Weekly, 43(11), pp. 41-43. (Review of The Perspectives Team (2007) Abandoned: Development and Displacement, New Delhi: Perspectives).

Vijayabaskar, M. (2014) 'The Politics of Silence', in Rob Jenkins, Lorraine Kennedy \& Partha Mukhopadhyay (eds.), Power, Policy and Protest: The Politics of India's Special Economic Zones, New Delhi: Oxford University Press, pp. 305-30.

Walker, Kathy Le Mons (2008) 'Neoliberalism on the Ground in Rural India: Predatory Growth, Agrarian Crisis, Internal Colonization, and the Intensification of Class Struggle', Journal of Peasant Studies, 35(4), pp. 557-620.

Whitehead, Judith (2012) 'The Neo-Liberal City: A Critical Geography', Economic and Political Weekly , 47(13), pp. 31-33. (Review of Banerjee-Guha, Swapna (ed.) (2010) Accumulation by Dispossession: Transformative Cities in the New Global Order, New Delhi: Sage.)

Wood, Ellen Meiksins (2002) The Origins of Capitalism: A Longer View, London and New York: Verso. 
Wood, Ellen Meiksins (2006) 'Logics of Power: A Conversation with David Harvey', Historical Materialism, 14(4), pp. 9-34.

\section{NOTES}

1. Comments from four anonymous reviewers are acknowledged with thanks.

2. See Levien's (2013) persuasive attempt to construct a periodization of modern Indian economic and political history in terms of 'regimes of dispossession'.

3. This conditionality is necessary to exclude deployment of appropriated land for a variety of other (non-capitalist) purposes, including extraction of precapitalist ground rent, enhancing social status and cultural prestige, political and particularistic conflicts, etc. (Adnan 2013, Hall 2013: 1592).

4. See Marx (1976: 875-76, 2010: 501-02 \& 527-31) and Perelman (1984: 8-12).

5. The objective of this article as well as constraints of space preclude detailed discussion of the theoretical criticisms of ABD. However, I have discussed these in earlier publications (Adnan 2013, 2014).

6. The CHT (Land Acquisition) Regulation, 1958.

7. The Panchayat (Extension to the Scheduled Areas) Act, 1996 (PESA).

\section{ABSTRACTS}

In this article, selected evidence from contemporary India and Bangladesh is analyzed to identify the diverse mechanisms of land alienation at work. A typology of such mechanisms is developed for this purpose, based on a critical review of theoretical approaches to primitive accumulation (Marx 1976) and accumulation by dispossession (ABD) (Harvey 2005). In this typology, mechanisms of land alienation and primitive accumulation can be direct or indirect and may or may not involve the use of force. Moreover, multiple mechanisms can operate in combination. The application of this typology to the empirical evidence shows that mechanisms of land alienation exist under all its broad categories. Accordingly, it is concluded that notions of primitive accumulation/ABD which are confined to extra-economic or non-market characterizations are unduly restrictive and correspond to special cases that cannot accommodate the entire range of mechanisms displayed by the evidence from neoliberal India and Bangladesh. Moreover, capitalism itself can operate as a driving force of ongoing primitive accumulation/ABD, corresponding to direct mechanisms of land alienation. Correlatively, primitive accumulation/ABD can be generated by autonomous factors and the lands so released can be potentially deployed in capitalist production, corresponding to indirect mechanisms of land alienation.

\section{INDEX}

Keywords: land grab, alienation, primitive accumulation, accumulation by dispossession, India, Bangladesh, neoliberalism 


\section{AUTHOR}

\section{SHAPAN ADNAN}

Associate, University of Oxford, Contemporary South Asian Studies Programme 